\title{
Beneficial effects of non-alcoholic grape-derived products on human health: A literature review
}

\author{
Chiara Di Lorenzo ${ }^{1}$, Luis Perez de Sousa ${ }^{2}$, Raul Francisco Pastor ${ }^{3}$, Francesca Colombo ${ }^{1}$, Gianfranco Frigerio ${ }^{1}$, \\ and Patrizia Restani ${ }^{1}$
${ }^{1}$ Dipartimento di Scienze Farmacologiche e Biomolecolari, Università degli Studi di Milano, via Balzaretti 9, 20133 Milan, Italy
${ }^{2}$ Instituto Politecnico de Beja, Rua Pedro Soares, Apartado 6155, 7800-295 Beja, Portugal
${ }^{3}$ Cuarta Cátedra de Medicina Interna, Hospital de Clínicas “José de San Martín”, Universidad de Buenos Aires, \\ Av. Córdoba 2351, Buenos Aires, Argentina
}

\begin{abstract}
Vine is widely cultivated due to the economic value of wine and other grape derivatives. The grape berry is characterized by the presence of a wide variety of flavonoids, which have been investigated for their health promoting properties. Several epidemiological studies have shown that a moderate consumption of wine is associated with a J-shaped effect on some risk factors for chronic diseases. On the other hand, the wine market has shown a decreasing trend due to the frequent abuse of alcoholic beverages also by young people, as denounced by WHO. Accordingly, the scientific research in the field of non-alcoholic grape products has been further stimulated. The aim of this paper was a preliminary collection of data on human studies supporting the beneficial properties of unfermented grape products. The most convincing positive effects, observed in humans, consisted in the reduction of risk factors for cardiovascular diseases, such as hypertension and oxidative stress. Other human trials have been published in the area of: immune system, diabetes, cognitive functions, oral health, and cancer. Generally speaking, the findings listed in this review support the use of non-alcoholic grape derivatives, as a source of beneficial compounds for the human diet, even though further studies are necessary.
\end{abstract}

\section{Introduction}

From the economically point of view, vine (Vitis spp.) is one of the most important plant species due to the production of wine, juice and other grape-derived products [1]. The grape berry is characterized by the presence of different classes of phytochemicals, which have been investigated for their health promoting properties. To date, more than 500 compounds have been identified in Vitis vinifera fruit and derivatives. The positive effects on human health are normally associated with the phenolic compounds [2]; most of them are flavonoids, classified as flavanols, flavonols and anthocyanins. Grape skins of red varieties and leaves contain mainly anthocyanins and flavonols. The most important anthocyanins are the 3-O-monoglucoside and the 3-O-acylated monoglucosides of delphinidin, cyanidin, petunidin, peonidin and malvidin. The most abundant flavonols are the 3-O-glycosides of myricetin, quercetin, kaempferol and isorhamnetin. Grape seeds, skin and stems are also important sources of proanthocyanidins (PROs), oligomers and polymers of (+)-catechin, (-)-epicatechin, and (-)-epicatechin gallate. In addition, skin and stems contain prodelphinidins, oligomers and polymers of (-)-epigallocatechin and trace amounts of (+)-gallocatechin and (-)-epigallocatechin gallate [2]. The beneficial effects of grape flavonoids have been widely studied since their association with the so-called "French Paradox" [3]. The term refers to the epidemiological observation of comparatively low incidence of coronary heart disease in the population of some Mediterranean regions, despite the presence of a local diet rich in saturated fats. The tradition of regular and moderate consumption of red wine was hypothesized as the main factor responsible for decreasing the risk for cardiovascular diseases [4]. On the other hand, the wine market has shown a decreasing trend due to the frequent abuse/misuse of alcoholic beverages also in young people; this social problem was faced in December 2009 by WHO with the paper "Strategies to reduce the harmful use of alcohol: draft global strategy" [5]. This social situation has stimulated the scientific research in the field of grape and its non-alcoholic derivatives (such as grape juices, extracts and raisins), which could be suitable alternative sources of healthy molecules. It has been suggested that the reduction of death from all causes, observed with moderate wine consumption, could be reproduced with the introduction in the diet of certain fruits, grains and vegetables, having similar content of phenolic compounds. Also OIV, in its strategic plan 2015-2019, underlines the importance of "evaluating, in collaboration with the FAO and the $\mathrm{WHO}$, the health aspects, nutritional potential and socio-behavioural factors of all non-alcoholic vine derived products". On this basis, the aim of this work is to provide a preliminary review on the different healthy effects associated with non-alcoholic grape products including table grapes, grape juice, raisins and seed/ skin extracts. 


\section{Methods}

PubMed/MEDLINE and Embase were systematically searched to create the present work. These databases are among the most important and comprehensive scientific tools for references/abstracts on life sciences and biomedical topics. The following search strategy and selection criteria were used: data were collected from database inception to April 2015, with the terms "grape", "raisins", "grape extract", "grape juice", in combination with "benefits" or "health". Using this search method, the main health-related effects, associated with grape derivative consumption, were easily identified. Some search limits were established and, for this paper, only studies performed in humans were collected and discussed. All classes of human intervention trials were selected, although randomized, placebo-controlled studies were considered to provide the most reliable evidences.

\section{Results and discussion}

The search by title and abstract allowed the collection of 518 publications. By removing the duplicates and the not pertinent papers, the final number of publications included was 56. Positive effects due to the consumption of grape and derivatives (apart from wine) were evidenced in the following areas: cardiovascular function (including oxidative stress, inflammation and metabolic syndrome), inflammation, immune function, diabetes, oral health, cancer, and cognitive function. The number of studies collected in each health area is listed in Table 1. Selected studies considered grape, juices, grape seed/skin extracts and raisins. Since the number of studies collected is very high, this paper will list only the number of citations supporting or not supporting a certain biological event. The most recent references will be cited, and will refer both to positive and negative results. A more comprehensive review will be prepared and sent for publication in a peerreviewed journal.

Table 1. Number of the studies involving non-alcoholic grape products and health areas investigated.

\begin{tabular}{|l|c|c|c|}
\hline & $\begin{array}{c}\text { Grape juice } \\
\text { and grape }\end{array}$ & $\begin{array}{c}\text { Grape } \\
\text { extracts }\end{array}$ & Raisins \\
\hline $\begin{array}{l}\text { Cardiovascular } \\
\text { function }\end{array}$ & 14 & 15 & 2 \\
\hline Diabetes & 2 & 1 & 3 \\
\hline $\begin{array}{l}\text { Inflammation and } \\
\text { immune function }\end{array}$ & 2 & 6 & 1 \\
\hline Cognitive function & 3 & - & - \\
\hline Cancer & 2 & 3 & - \\
\hline Oral health & - & 1 & 1 \\
\hline Total papers & $\mathbf{2 3}$ & $\mathbf{2 6}$ & $\mathbf{7}$ \\
\hline
\end{tabular}

\subsection{Cardiovascular (CV) function}

Cardiovascular disease is the leading cause of death in the United States and Europe for both men and women among
Table 2. Studies assessing the effects of unfermented grape derivatives on parameters associated with $\mathrm{CV}$ diseases.

\begin{tabular}{|l|c|c|c|}
\hline Parameter & $\begin{array}{c}\text { Papers } \\
\text { with positive } \\
\text { effects }\end{array}$ & $\begin{array}{c}\text { Papers with } \\
\text { no significant } \\
\text { difference }\end{array}$ & Ref. \\
\hline $\begin{array}{l}\text { Endothelial } \\
\text { function as FMD }\end{array}$ & $\begin{array}{c}11 \\
\text { (GJ, GE) }\end{array}$ & $\begin{array}{c}3 \\
\text { (GJ, GSE) }\end{array}$ & $\begin{array}{c}9, \\
12-14\end{array}$ \\
\hline $\begin{array}{l}\text { Inflammatory } \\
\text { biomarkers }\end{array}$ & $\begin{array}{c}7 \\
\text { (GJ, GE, R) }\end{array}$ & $\begin{array}{c}7 \\
\text { (GJ, GE) }\end{array}$ & 21,24 \\
\hline $\begin{array}{l}\text { Oxidative stress } \\
\text { (LDL-oxidation) }\end{array}$ & $\begin{array}{c}8 \\
\text { (GJ, GE, R) }\end{array}$ & $\begin{array}{c}4 \\
\text { (GJ, GE) }\end{array}$ & $\begin{array}{c}13, \\
20-22\end{array}$ \\
\hline $\begin{array}{l}\text { Blood lipids } \\
\text { (LDL-CHO, } \\
\text { triglycerides) }\end{array}$ & $\begin{array}{c}4 \\
\text { (GJ, GE, R) }\end{array}$ & 13,15 \\
\hline $\begin{array}{l}\text { Blood pressure } \\
\text { reduction }\end{array}$ & $\begin{array}{c}5 \\
\text { (GJ, G/GSE, R) }\end{array}$ & $\begin{array}{c}1 \\
\text { (GSE) }\end{array}$ & $19-20$ \\
\hline $\begin{array}{l}\text { Platelet } \\
\text { aggregation }\end{array}$ & 1 & 4 & $9-11$ \\
\hline
\end{tabular}

G: Grape; GE: Grape Extract; GSE: grape seed extract; R: raisins; CHO: cholesterol; FMD: flow-mediated-dilatation.

all racial and ethnic groups. Epidemiological and experimental evidences suggest a protective effect on cardiovascular diseases and stroke of a diet containing foods, rich in polyphenols [6]. As reported in Table 2, most studies investigating the effects of grape juice and grape extracts measured urinary isoprostanes, total and LDL cholesterolemia, LDL oxidation, endothelial function, platelet aggregation and inflammatory cytokine levels, which are among the most widely recognized biomarkers for cardiovascular diseases $[7,8]$. The most important positive effects reported were: 1) the reduction of systolic blood pressure (5 papers with positive association and one with no significant difference versus control) [9-11]; 2) the improvement of endothelial functions, assessed by measuring the flow-mediated- dilatation (FMD) of the brachial artery (11 in favour and 3 without significant results) [9,12-14]. Encouraging results were observed on systolic blood pressure; in fact 5 papers out of 6 indicated a reduction of this parameter in both healthy and pre-hypertensive subjects after the consumption of one cup daily (for 42 days) of raisins or a snack containing raisins 3 times a day (for 84 days) $[15,16]$.

In particular, a supplementation of purple grape juice (640 or $320 \mathrm{~mL} /$ day for 28 days), in adults with severe endothelial dysfunction, significantly increased the FMD of the brachial artery from $1.3 \pm 2.3$ to $2.9 \pm 3.9 \%$ [17] A similar effect on FMD was observed in adolescents affected by metabolic syndrome [12] and in adults with coronary artery disease [19]. The investigators suggested that the observed effects were due to the enhancement in the nitric oxide (NO) bioactivity, responsible for the positive modulation of endothelial function. Controversial results were observed on the improvement of plasma cholesterol profile (reduction of LDL-cholesterol mediated by an increased expression of LDL receptors) after the intake of grape derivatives (4 studies in favour and 4 without significant difference) $[13,15,19,20]$, while significant 
results were reported on LDL-oxidation (8 studies versus 4) $[13,20-22]$. Few studies, enrolling healthy subjects, evaluated the effects of grape juice on platelet aggregation; the results on this effect are not sufficiently supported ( 1 paper in favour and 4 without significant difference) [23-26].

Generally speaking, controversial results have been obtained on the reduction of inflammatory parameters associated with cardiovascular diseases after supplementation with grape juice and extracts. For example, Albers et al. (2004) [25] showed a significant reduction of soluble CD40 ligand (sCD40L) in 20 subjects affected by coronary diseases after consumption of purple grape juice $(490 \mathrm{~mL} /$ day for 14 days). A significant reduction of the inflammatory markers sICAM-1 (soluble intercellular adhesion molecule) was measured in subjects affected by metabolic syndrome after the consumption of $46 \mathrm{~g} /$ day of a food supplement containing grape seed extract (corresponding to 2 servings/day of fresh grapes) [9]. Other papers did not find any significant difference versus control groups (see Table 2).

\subsection{Diabetes/obesity}

Type 2 diabetes is a chronic disease characterized by hyperglycaemia, peripheral resistance to the action of insulin, and a reduced activity of insulin-producing $\beta$-cells in the pancreas. Obesity is among the most important risk factors for diabetes. Other risk factors include family history, physical inactivity, hypercholesterolemia, hypertriglyceridemia, and hypertension. Results from epidemiological studies on the relationship between dietary flavonoids and development of type 2 diabetes are controversial [27]. In addition, only few human studies have considered the effects of grape derivatives, apart from wine, on metabolic parameters associated with diabetes (Table 3 ). Since the Glycemic Index (GI) of grape falls within the low range, this fruit is considered appropriate for inclusion in a diet targeting low glycemic foods, like that for diabetic individuals [28].

Table 3. Studies assessing the effects of unfermented grape derivatives on parameters associated to diabetes.

\begin{tabular}{|l|c|c|c|}
\hline Parameter & $\begin{array}{c}\text { Papers } \\
\text { supporting } \\
\text { a positive } \\
\text { effect }\end{array}$ & $\begin{array}{c}\text { Papers } \\
\text { with no } \\
\text { significant } \\
\text { difference }\end{array}$ & Ref. \\
\hline Insulin response & $\begin{array}{c}4 \\
\text { (GJ, GE) }\end{array}$ & $\begin{array}{c}1 \\
\text { (R) }\end{array}$ & $29-32$ \\
\hline $\begin{array}{l}\text { Fasting and post- } \\
\text { prandial glycaemia }\end{array}$ & $\begin{array}{c}2 \\
\text { (GJ, R) }\end{array}$ & $\begin{array}{c}1 \\
(\mathrm{GJ})\end{array}$ & $16,29,31$ \\
\hline $\begin{array}{l}\text { Glycated } \\
\text { haemoglobin }\end{array}$ & $\begin{array}{c}1 \\
(\mathrm{GJ})\end{array}$ & $\begin{array}{c}1 \\
(\mathrm{R})\end{array}$ & 16,29 \\
\hline $\begin{array}{l}\text { Reduction of food } \\
\text { intake }\end{array}$ & $\begin{array}{c}1 \\
(\mathrm{R})\end{array}$ & $\begin{array}{c}1 \\
\text { (GJ) }\end{array}$ & 31,33 \\
\hline $\begin{array}{l}\text { Modulation body } \\
\text { weight }\end{array}$ & - & - & 32 \\
\hline Oxidative stress & 1 & $(\mathrm{GJ})$ & 32 \\
\hline
\end{tabular}

Abbreviations as in Table 2.
Banini et al. [29] investigated in 29 subjects affected by type 2 diabetes the effects of the consumption of $150 \mathrm{~mL} /$ day of grape juice, wine and dealcoholized wine from Vitis rotundifolia (muscadine). Fasting blood glucose levels, insulin response and the concentration of glycated haemoglobin were measured. Subjects receiving the dealcoholized wine for 28 days showed reduced fasting blood insulin levels compared to other groups. In addition, the blood glucose/insulin ratio in fasting condition increased from 8.5 to 13.1 during the 28-day intervention study. This effect was considered positive, since a glucose/insulin ratio $<7$ is predictive of insulin resistance. No difference in fasting blood glucose, insulin, or glycated haemoglobin levels was observed before and after the intervention study in groups consuming muscadine grape juice or wine [29].

These preliminary positive results could be due to those polyphenols, found in grapes or vine-derived products, which have shown inhibitory effects in animal models, where diabetes was chemically induced. Furthermore, some authors showed that the grape procyanidins increased the uptake of glucose in adipocyte cell lines, where procyanidins could have an insulin mimetic effect [34].

In a study involving 38 overweight/obese and firstdegree relatives of type 2 diabetic patients, an increase of hepatic insulin sensitivity and a reduction of the oxidative stress were shown after a supplementation with $2 \mathrm{~g} /$ day of a red grape extract in comparison with subjects receiving placebo [32]. The positive effects of grapes on oxidative stress is supported by in vitro studies, where proanthocyanidins and resveratrol decreased lipid peroxidation and increased pancreatic glutathione levels [35]. These data, if confirmed by human studies, indicate that the grape seed proanthocyanidins can protect $\beta$-cell function and suggest a protective effect against generation of damaging reactive oxygen species.

Raisins, like other dried fruits, have been generally considered unsuitable in the diet of obese and diabetic subjects due to the high sugar content and the energy contribution. As a consequence, the insulin response to raisins has been evaluated only in few studies. This parameter was evaluated in 1) sedentary adults; 2) prediabetic individuals; and 3) aerobically trained subjects by Kim et al. in 2008 [34]. In all subjects, the GI after raisins consumption was approximately 50 with no difference between groups (each group $n=10$ ); in addition, the serum insulin AUC (Area Under the Curve) in response to the intake of $69 \mathrm{~g}$ raisins was lower if compared with glucose. The glycaemic and insulin index were higher in endurance athletes (62 \pm 5 and $57 \pm 7$, respectively), but the difference with the other groups was not statistically significant. In a study by Bays et al. (2012) performed in 46 healthy subjects, the consumption of a snack containing raisins, three times/ day, determined a significant reduction of postprandial glycaemia (16\%) [16]. Among the positive effects for diabetic subjects associated with the consumption of raisins, there is the promotion of satiety by affecting the levels of hormones involved in the regulation of appetite [36]. Moreover, cumulative energy intake (calculated as total kcal introduced) was lower in the groups taking water or the raisins snack versus those consuming grape or other usual snacks, such as chocolate cookies or potato chips $(\mathrm{p}<0.031)$ [33]. Despite the promising results, considering the paucity of data available, further studies are needed 
to investigate the potential health benefits of grape and derivatives in this area.

\subsection{Neurocognitive function}

The number of subjects suffering from dementia worldwide is currently estimated in more than 35 million and is projected to reach more than 81 million cases by the year 2040 [37]. Mild cognitive impairment represents an important risk factor for dementia, and progression from mild cognitive impairment to Alzheimer's disease can be as high as $10 \%$ per year [38].

The regulation of inflammatory processes, often decreased with ageing, is associated with an acceleration of neurodegenerative disorders. In in vitro studies berry fruits (including grape) containing a good polyphenol profile have shown anti-inflammatory and antioxidant properties, which could support neuroprotective effects [39]. To date, these positive effects on human health have been rarely investigated (Table 4).

Only two studies, conducted by Krikorian et al. (2010 and 2012) evaluated the effects of the supplementation of concord grape juice on cognitive function in older adults with cognitive impairment $[40,41]$. In both studies participants with forgetfulness and prospective memory lapses received Concord grape juice for 12 and 16 weeks, respectively. In the first study a significant improvement in a measure of verbal learning $(P=0.04)$, but not of verbal and spatial recall, was observed in those subjects receiving concord grape juice. In the study performed by the same authors in 2012, a significant improvement of memory was observed after concord grape juice intake for 16 weeks and this effect was scientifically supported by the grater activation in anterior and posterior regions of the right hemisphere measured by magnetic resonance imaging [41]. In order to explain the results obtained, authors speculated that anthocyanins could be involved in the reduction of oxidative stress and inflammatory markers in brain tissues.

Table 4. Studies assessing the effects of unfermented grape derivatives on cognitive function.

\begin{tabular}{|l|c|c|c|}
\hline Parameter & $\begin{array}{c}\text { Papers } \\
\text { supporting } \\
\text { a positive } \\
\text { effect }\end{array}$ & $\begin{array}{c}\text { Papers } \\
\text { with no } \\
\text { significant } \\
\text { difference }\end{array}$ & Ref. \\
\hline $\begin{array}{l}\text { Verbal learning in old } \\
\text { adults with cognitive } \\
\text { impairment }\end{array}$ & 1 & - & 40 \\
\hline $\begin{array}{l}\text { Verbal and spatial } \\
\text { recall in old adults with } \\
\text { cognitive impairment }\end{array}$ & - & 1 & 40 \\
\hline $\begin{array}{l}\text { Memory improvement } \\
\text { in old adults with } \\
\text { cognitive impairment }\end{array}$ & $\begin{array}{c}\text { (GJ) } \\
\text { (GJ) }\end{array}$ & - & 41 \\
\hline $\begin{array}{l}\text { Calme rating and speed } \\
\text { attention in young } \\
\text { subjects }\end{array}$ & \begin{tabular}{c} 
(GJ) \\
\hline $\begin{array}{l}\text { Memory in young } \\
\text { subjects }\end{array}$
\end{tabular} & 1 & 42 \\
\hline
\end{tabular}

Abbreviations as in Table 2.
Another study was performed in 20 healthy young adults, who received in single dose $200 \mathrm{~mL}$ of Concorde purple grape juice or placebo (sugar and flavour) [42]. After 30 min from intake, a significant increase of calme ratings $(p<0.05)$ and an improvement in speed of attention $(p<0.05)$ were observed. No effect on memory was registered.

\subsection{Cancer}

As shown in Table 5, few papers in humans (with controversial results) have been published on the relationship between unfermented grape derivatives and prevalence of cancer, apart from epidemiological studies showing a protective property of a diet rich in fruits and vegetables [43].

Brooker et al. (2006) investigated whether a grape seed extract was effective, compared to placebo, in reducing tissue induration after high-dose radiotherapy in sixty-six women with early breast cancer [44]. After 12 months, no significant difference was recorded between treatment and control groups in terms of external assessment of tissue hardness, breast appearance or patient self-assessment of breast hardness.

Chen et al. (2014) measured the colorectal cancer progression in patients receiving the antitumoral 5-fluorouracil with or without a food supplement containing vegetable derivatives, including grape seed extract [45]. No significant difference was observed in overall response rate and overall survival, but patients receiving the food supplement had a significant reduction of disease progression rate. A study was performed in 67 healthy adults (16 women and $51 \mathrm{men}$ ) to evaluate if a daily regimen of grape juice consumption (480 mL/day for 8 weeks)

Table 5. Studies assessing the effects of unfermented grape derivatives on cancer.

\begin{tabular}{|l|c|c|c|}
\hline Parameter & $\begin{array}{c}\text { Papers } \\
\text { supporting } \\
\text { a positive } \\
\text { effect }\end{array}$ & $\begin{array}{c}\text { Papers } \\
\text { with no } \\
\text { significant } \\
\text { difference }\end{array}$ & Ref. \\
\hline $\begin{array}{l}\text { Tissue induration after } \\
\text { radiotherapy in women } \\
\text { with early breast cancer }\end{array}$ & $\begin{array}{c}1 \\
\text { (GSE) }\end{array}$ & 44 \\
\hline $\begin{array}{l}\text { Overall response rate } \\
\text { of colorectal cancer } \\
\text { progression in patients } \\
\text { receiving the antitumoral } \\
\text { 5-fluoro- uracil }\end{array}$ & - & 1 & 45 \\
\hline $\begin{array}{l}\text { Reduction of disease } \\
\text { progression rate in the } \\
\text { group of patient above }\end{array}$ & 1 & - & 45 \\
\hline $\begin{array}{l}\text { Reduction of DNA } \\
\text { damage in peripheral } \\
\text { lymphocytes and ROS } \\
\text { release }\end{array}$ & (GJ) & - & 46 \\
\hline $\begin{array}{l}\text { Reduction of breast } \\
\text { cancer risk in pre- and } \\
\text { post-menopausal women }\end{array}$ & (G) & & 47 \\
$\begin{array}{l}\text { Abbreviations as in Table 2. } \\
\text { ^ Mixture of vegetable extracts, including GSE. }\end{array}$ & \\
\hline
\end{tabular}


reduced the DNA damage in peripheral lymphocytes and the amount of free endogenous reactive oxygen species (ROS) released [46]. Grape juice consumption determined a significant decrease of DNA damage before and after the period of supplementation. Moreover a reduction by $15 \%$ was observed in free radical release, compared to the beginning of the supplementation. These findings supported a possible cancer-protective property of grape juice on lymphocytes, due to the reduced release of ROS.

A study by Do et al. [47] examined the relationship between fruit and vegetable consumption on breast cancer risk in pre- and post-menopausal Korean women. High grape intake demonstrated an inverse association on breast cancer incidence in post-menopausal women $(\mathrm{OR}=0.59)$.

\subsection{Inflammation and immune system}

Inflammation is the first body's response to infection or injury, and a critical process for both innate and adaptive immunity. It can be considered as part of the complex biological response of vascular tissues to harmful stimuli, such as pathogens, damaged cells, or irritants. Uncontrolled inflammation often results in chronic diseases, such as arthritis, autoimmune disorders, degenerative joint diseases, rheumatisms, atherosclerosis, diabetes and even cancer.

Several mediators participate to the inflammatory process; some are released in the first steps (i.e. histamine, serotonin, etc.), others are synthesized and released within a short time (prostaglandins, leukotrienes, platelet-activating factor, etc.), others require a de novo synthesis (cytokines, adhesion molecules, etc.). Several cytokines cooperate to induce the gene expression of specific promoters. The induction of most among these genes is dependent on the presence of binding sites for the nuclear factor $\mathrm{kB}(\mathrm{NF}-\mathrm{kB})$, which regulates genes involved in many aspects of the inflammatory response [48]. In response to a variety of pro-inflammatory stimuli, such as cytokines or oxidative stress, NF-kB transcription factor induces pro-inflammatory genes encoding for the synthesis of cytokines, chemokines, adhesion molecules, such as intercellular adhesion molecules-1 (ICAM-1), E selectin, cyclooxygenase-1 (COX-1) and 2, inducible nitric oxide synthase (iNOS) and metalloproteases (MMP).

Little research has been performed to evaluate the antiinflammatory effects of unfermented grape products. A recent review [49] has summarized the results obtained in human intervention trials and in epidemiological studies, which evaluated the effects of unfermented grape derivatives in different pathological conditions and in healthy subjects. Table 6 lists the studies on the effects of different grape derivatives in healthy subjects and in systemic sclerosis. Positive preliminary results have been obtained in the reduction of biomarkers of oxidative stress (e.g. glutathione peroxidase levels and malondialdehyde-modified LDL) and inflammation (E-selectin and ICAM-1) after consuming grape seed extracts by healthy subjects and patients affected by systemic sclerosis [50-54]. Even though, the available data are promising, new studies are necessary to confirm the positive results.

Two studies reported positive results on the immune system when middle-aged and aged subjects consumed
Table 6. Studies assessing the effects of unfermented grape derivatives on inflammation and immune system.

\begin{tabular}{|c|c|c|c|}
\hline Parameter & $\begin{array}{l}\text { Papers } \\
\text { supporting } \\
\text { a positive } \\
\text { effect }\end{array}$ & $\begin{array}{l}\text { Papers } \\
\text { with no } \\
\text { significant } \\
\text { difference }\end{array}$ & Ref. \\
\hline $\begin{array}{l}\text { Reduction of oxidative } \\
\text { stress in healthy subjects } \\
\text { (production of MDA) }\end{array}$ & $\begin{array}{c}2 \\
(\mathrm{GSE})\end{array}$ & $\begin{array}{c}1 \\
(\mathrm{GSKE})\end{array}$ & $\begin{array}{c}50 \\
53-54\end{array}$ \\
\hline $\begin{array}{l}\text { Reduction of oxidative } \\
\text { stress in healthy subjects } \\
\text { (glutathione peroxidase } \\
\text { activity) }\end{array}$ & $\begin{array}{c}1 \\
(\mathrm{GSE})\end{array}$ & - & 53 \\
\hline $\begin{array}{l}\text { Reduction of } \\
\text { inflammation in systemic } \\
\text { sclerosis (reduction of } \\
\text { E- selectin) }\end{array}$ & $\begin{array}{c}1 \\
(\mathrm{GSE})\end{array}$ & - & 50 \\
\hline $\begin{array}{l}\text { Reduction of } \\
\text { inflammation in systemic } \\
\text { sclerosis (reduction of } \\
\text { ICAM-1) }\end{array}$ & $\begin{array}{c}1 \\
(\mathrm{GSE})\end{array}$ & - & 50 \\
\hline $\mathrm{T}$-cell proliferation & $\begin{array}{c}2 \\
(\mathrm{GJ})\end{array}$ & - & 56 \\
\hline $\begin{array}{l}\text { Level of T-cell } \\
\text { cytochines }\end{array}$ & - & $\begin{array}{c}1 \\
(\mathrm{GE})\end{array}$ & 19 \\
\hline
\end{tabular}

GSKE: grape skin extract; MDA: malondialdehyde; ICAM-1: intercellular adhesion molecule-1. Other abbreviation as in Table 2.

Concord grape juice for 9-10 weeks. When compared to placebo, an increase of T-cell proliferation and a higher serum vitamin $\mathrm{C}$ level were observed [55].

Moreover, Zunino et al. [19] measured the T-cell cytochine production in obese subjects after the consumption of grape extract for 21 days. No significant difference was observed compared to control group.

\subsection{Oral health}

Some data on other research areas have been published and collected for this preliminary review. In particular, the effects of non-alcoholic grape derived products were investigated in oral health.

Surprisingly, some positive results were obtained when the effects of raisins were evaluated in oral health. In fact, raisins are generally considered cariogenic for their stickiness and acidogenicity [57]. However, when the effect of raisins and raisin-containing bran cereal on plaque acidogenicity was examined in 7- to 11-year-old children, it was observed that raisins did not reduce the teeth plaque $\mathrm{pH}$ below 6 over the 30 -min test period. If confirmed by further studies, these data could support raisins as a healthy alternative to the commonly consumed sweet snack foods [58].

In vitro studies showed that also grape seed extracts, which contain high amount of proanthocyanidins, positively affected the demineralization and/or remineralization processes of artificial root caries lesions, suggesting their use as promising natural agents for noninvasive root caries prevention $[59,60]$. 


\section{Conclusion}

The results presented in this review underline some wellestablished beneficial effects of unfermented grape products on cardiovascular health, such as the improvement of endothelial function and a reduction of LDL oxidation, factors which have been associated with the atherosclerosis process progression. Despite the paucity of data about raisins, promising results have been obtained in cardiovascular area, thanks to the observed reduction of oxidative stress and blood pressure.

Some papers reported the positive effects of grape products in diabetes; in fact grape juice, grape extracts and raisins seemed responsible for beneficial effects mediated by an increased hepatic insulin sensitivity and reduced plasmatic postprandial glycaemia. Raisins, included in some studies in form of snack, showed to be useful in reducing appetite and the total meal-energy intake in children. Other promising areas of research, where unfermented grape products have shown preliminary positive results, are related to the neurocognitive function, immune system and oral health.

Generally speaking, some limitations and critical points were identified in all studies reviewed. Among them: 1) diet and lifestyle modifications during intervention were not always detailed; 2) differences in background diets between intervention and control groups were scarcely considered although strongly associated with the changes in biological markers during intervention; 3 ) a very small number of participants was enrolled in the majority of the trials collected; 4) polyphenol content and phytochemical characterization of the grape products, used in the studies, were rarely detailed. Further studies in humans, including a more suitable number of subjects, are required to confirm the findings showed in this review and to investigate in humans other positive effects, which are only speculatively supported by in in vitro or in animal models.

Chiara Di Lorenzo thanks OIV for the research grant, which supported partially this study.

\section{References}

[1] K. Ali, F. Maltese, Y. Choi, R. Verpoorte, Phytochem. Rev. 9, 357 (2010)

[2] C. Stockley, P.L. Teissedre, M. Boban, C. Di Lorenzo, P. Restani, Food Funct. 3, 995 (2012)

[3] A.S. Leger, A.L. Cochrane, F. Moore, Lancet 1, 1017 (1979)

[4] S. Renaud, M. De Lorgeril, Lancet, 339, 1523 (1992)

[5] WHO available at: www. who.int/substance_abuse/msbalcstrategy.pdf, last access 4 th May 2015

[6] G. Williamson, A. Carughi, Nutr. Res. 30, 511 (2010)

[7] A. Avolio, G. Grassi, J. Hypertens. 26, 1546 (2008)

[8] E. Verhoye, M.R. Langlois, Clin. Chem. Lab. Med. 47, 128 (2009)

[9] J. Barona, J.C. Aristizabal, C.N. Blesso, J.S. Volek, M.L. Fernandez, J. Nutr. 142, 1626 (2012)

[10] M.M. Dohadwala, M. Holbrook, N.M. Hamburg, S.M. Shenouda, W.B. Chung, M. Titas, M.A. Kluge,
N. Wang, J. Palmisano, P.E. Milbury, J.B. Blumberg, J.A. Vita, Am. J. Clin. Nutr. 93, 934 (2010)

[11] R.T. Ras, P.L. Zock, Y.E.M.P. Zebregs, N.R. Johnston, D.J. Webb, R. Draijer, Br. J. Nutr. 110, 2234 (2013)

[12] M. Hashemi, R. Kelishadi, M. Hashemipour, A. Zakerameli, N. Khavarian, S. Ghatrehsamani, P. Poursafa, Cardiol. Young 20, 73 (2010)

[13] A.A. Chaves, M.S. Joshi, C.M. Coyle, Vascul. Pharmacol. 50, 20 (2009)

[14] L.A.J. van Mierlo, P.L. Zock, H.C.M. van der Knaap, R. Draijer, J. Nutr. 140, 1769 (2010)

[15] M.J. Puglisi, U. Vaishnav, S. Shrestha, M. Torres- Gonzalez, R.J. Wood, J.S. Volek, M.L. Fernandez, Lipids Health 7, 14 (2008)

[16] H.E. Bays, K. Schmitz, A. Christian, M. Ritchey, J. Anderson, J. Am. Coll. Cardiol. 59, E1721 (2012)

[17] E.J. Chou, J.G. Keevil, S. Aeschlimann, D.A. Wiebe, J.D. Folts, J.H. Stein, Am. J. Cardiol. 88, 553 (2001)

[18] J.H. Stein, J.G. Keevil, D.A. Wiebe, S. Aeschlimann, J.D. Folts, Circulation 100, 1050 (1999)

[19] S.J. Zunino, J.M. Peerson, T.L. Freytag, A.P. Breksa, E.L. Bonnel, L.R. Woodhouse, D.H. Storms, Br. J. Nutr. 112, 369 (2014)

[20] T.L. Zern, R.J. Wood, C. Greene, K.L. West, Y. Liu, D. Aggarwal, N.S. Shachter, M.L. Fernandez, J. Nutr. 135, 1911 (2005)

[21] J.W. Rankin, M.C. Andreae, C.Y. Oliver Chen, S.F. O'Keefe, Diabetes Obes. Metab. 10, 1086 (2008)

[22] C.K. Blair, A.S. Kelly, J. Stainberger, L.E. Eberly, C. Napurski, K. Robien, J.P. Neglia, D.A. Mulrooney, J.A. Ross, Pediatr. Blood Cancer 61, 2290 (2014)

[23] S.F. Shenoy, C.L. Keen, S. Kalgaonkar, J.A. Polagruto, Thromb. Res. 121, 431 (2007)

[24] A.R. Albers, S. Varghese, O. Vitseva, J.A. Vita, J.E. Freedman, Arterioscler. Thromb. Vasc. Biol. 24, 179 (2004)

[25] S.R. Coimbra, S.H. Lage, L. Brandizzi, V. Yoshida, P.L. da Luz, Braz. J. Med. Biol. Res. 38, 1339 (2005)

[26] J.G. Keevill, H.E. Osman, J.D. Reed, J.D. Folts, J. Nutr. 130, 53 (2000)

[27] C-C. Chuang, M.K. McIntosh, Ann. Rev. Nutr. 31, 155 (2011)

[28] S. Zunino J. Nutr. 139, 1794S (2009)

[29] A.E. Banini, L.C. Boyd, J.C. Allen, H.G. Allen, D.L. Sauls, Nutrition 22, 1137 (2006)

[30] Y. Kim, S.R. Hertzler, H.K. Byrne, C.O. Mattern, Nutr. Res. 5, 304 (2008)

[31] J.H. Hollis, J.A. Houchins, J.B. Blumberg, R.D. Mattes, J. Am. Coll. Nutr. 28, 574 (2009)

[32] M. Hokayem, E. Blond, H. Vidal, K. Lambert, E. Meugnier, C. Feillet-Coudray, C. Coudray, S. Pesenti, C. Luyton, S. Lambert-Porcheron, V. Sauvinet, C. Fedou, J.F. Brun, J. Rieusset, C. Bisbal, A. Sultan, J. Mercier, J. Goudable, A.M. Dupuy, J.P. Cristol, M. Laville, A. Avignon, Diabetes Care 36, 1454 (2012) 
[33] B.P. Patel, B. Luhovyy, R. Mollard, J.E. Painter, G.H. Anderson, Appl. Physiol. Nutr. Metab. 38, 382 (2013)

[34] M. Pinent, M. Blay, M.C. Bladé, M.J. Salvadó, L. Arola, A. Ardévol, Endocrinology 145, 4985 (2004)

[35] A.T. El-Alfy, A.A.E. Ahmed, A.J. Fatani, Pharmacol. Res. 52, 264 (2005)

[36] M.J. Puglisi, G. Mutungi, P.J. Brun, M.M. McGrane, C. Labonte, J.S. Volek, M.L. Fernandez, Metabolism 58, 120 (2009)

[37] C.P. Ferri, M. Prince, C. Brayne, H. Brodaty, L. Fratiglioni, M. Ganguli, K. Hall, M.J. Puglisi, U. Vaishnav, S. Shrestha, M. Torres-Gonzalez, R.J. Wood, J.S. Volek, K. Hasegawa, H. Hendrie, Y. Huang, A. Jorm, C. Mathers, P.R. Menezes, E. Rimmer, M. Scazufca, Lancet 366, 2112 (2005)

[38] R.C. Petersen, J. Intern. Med. 256, 183 (2004)

[39] K. Ishige, D. Schubert, Y. Sagara, Free Radic. Biol. Med. 30, 433 (2001)

[40] R. Krikorian, E.L. Boespflug, D.E. Fleck, A.L. Stein, J.D. Wightman, M.D. Shidler, S. Sadat-Hossieny, J. Agric. Food Chem. 60, 5736 (2012)

[41] R. Krikorian R., T.A. Nash T.A., M.D. Shidler M.D., B. Shukitt-Hale B., J.A. Joseph J.A., Br. J. Nutr. 103, 730 (2010)

[42] C.F. Haskell, R. Stuart, Proc. Nutr. Soc. 72, (OCE4), E194 (2013)

[43] Z. Chen, P.P. Wang, J. Woodrow, Y. Zhu, B. Roebothan, J.R. McLaughlin, P.S. Parfrey, Nutr. J. 14, 8 (2015)

[44] S. Brooker, S. Martin, A. Pearson, D. Bagchi, J. Earl, L. Gothard, E. Hall, L. Porter, J. Yarnold, Radiother. Oncol. 79, 45 (2006)

[45] W.T. Chen, T.S. Yang, H.C. Chen, H.C. Chiang, T.C. Lin, C.H. Yeh, T.W. ke, J.S. chen, K.H. Hsiao, M.L. Kuo, Nutr. Res. 34, 585 (2014)
[46] Y.K. Park, E. Park, J-S. Kim, M-H. Kang, Mutat. Res. 529, 77 (2003)

[47] M.H. Do, S.S. Lee, J.Y. Jung, M.H. Lee, Int. J. Vitam. Nutr. Res. 77, 130 (2007)

[48] G. Bonizzi, M. Karin, Trends Immunol. 25, 280 (2004)

[49] M. Dell'Agli, C. Di Lorenzo, M. Badea, E. Sangiovanni, L. Dima, E. Bosisio, P. Restani, Cr. Rev. Food Sci. Nutr. 53, 403 (2013)

[50] R. Kalfin, A. Righi, A.D. Rosso, D. Bagchi, S. Generini, S. Guiducci, M.M. Cerinic, D.K. Das, Free Radical Res. 36, 819 (2002)

[51] P. Castilla, R. Echarri, A. Dávalos, F. Cerrato, H. Ortega, J.L. Teruel, M.F. Lucas, D. Gómez- Coronado, J. Ortuño, M.A. Lasunción, Am. J. Clin. Nutr. 84, 252 (2006)

[52] P. Castilla, A. Dávalos, J.L. Teruel, F. Cerrato, M. Fernández-Lucas, J.L. Merino, C.C. Sánchez-Martín, J. Ortuño, M.A. Lasunción, Am. J. Clin. Nutr. 87, 1053 (2008)

[53] J.F. Young, L.O. Dragsted, B. Daneshvar, S.T. Lauridsen, M. hansen, B. Sandstrom, British J. Nutr. 85, 505 (2000)

[54] A. Sano, R. Uchida, M. Saito, N. Shioya, Y. Komori, Y. Tho, N. Hashizume, J. Nutr. Sci. Vitaminol. (Tokyo) 53, 174 (2007)

[55] S.S. Percival, J. Nutr. 139, 1801S (2009)

[56] C.A. Rowe, M.P. Nantz, C. Nieves Jr, R.L. West, S.S. Percival, J. Med. Food 14, 69 (2011)

[57] S.A. Mundorff, J.D. Featherstone, B.G. Bibby, M.E. Curzon, A.D. Eisenberg, M.A. Espeland, Caries Res. 24, 344 (1990)

[58] A. Utreja, P. Lingstrom, L.B. Salzmann, C.A. Evans, C.D. Wu, Pediatr. Dent. 31, 498 (2009)

[59] Q. Xie, A.K. Bedran-Russo, C.D. Wu, J. Dent. 36, 900 (2008)

[60] C.D. Wu, J. Nutr. 139, 1818 S (2011) 